ISSN 1392-3196 / e-ISSN 2335-8947

Zemdirbyste-Agriculture, vol. 100, No. 2 (2013), p. 167-174

DOI 10.13080/z-a.2013.100.021

\title{
Genotype and microclimate conditions influence ripening pattern and quality of blackcurrant (Ribes nigrum L.) fruit
}

\author{
Hedi KALDMÄE, Ave KIKAS, Liina ARUS, Asta-Virve LIBEK \\ Polli Horticultural Research Centre, \\ Institute of Agricultural and Environmental Sciences, Estonian University of Life Sciences \\ Polli, 69104 Karksi-Nuia, Estonia \\ E-mail: hedi.kaldmae@emu.ee
}

\begin{abstract}
Blackcurrant (Ribes nigrum L.) fruit is valued for its content of nutritional compounds essential for human health. Traditionally, major part of the production has been used for processing but in recent years, the use of these valuable berries for fresh consumption has increased. The quality of fruit in terms of fruit size and nutritional content is especially important for dessert type cultivars and therefore more attention is paid to these in the present blackcurrant breeding programs. At Polli Horticultural Research Centre of the Estonian University of Life Sciences, Institute of Agricultural and Environmental Sciences, fruit quality aspects of 3 genotypes ('Almo', 'Karri', 'Asker') from our own breeding program and 6 introduced cultivars 'Ben Alder' (Scotland), 'Intercontinental', 'Titania', 'Öjebyn' (Sweden), 'Pamjati Vavilova' (Belarus) and 'Zagadka' (Russia), were investigated. Fruit ripening dynamics and fruit size, soluble solids content $\left({ }^{\circ} \mathrm{Brix}\right)$, sugar, acid and ascorbic acid content were evaluated in 2006-2010. The largest fruit was produced by the cultivars 'Intercontinental' and 'Karri'. Fruit of the cultivar 'Titania' have high content of sugar and acids, while 'Karri' has high sugar and low acid content. The most stable genotypes in respect of the majority of investigated parameters were 'Karri' and 'Zagadka'. 'Asker' distinguished from others by high and relatively stable vitamin $\mathrm{C}$ content.
\end{abstract}

Key words: ascorbic acid, breeding, fruit weight, Ribes nigrum, sugar, temperature, titratable acid.

\section{Introduction}

The growing trend of consumer interest in blackcurrant is largely due to the variety of potentially health beneficial bioactive compounds such as antioxidants (Hummer, Barney, 2002; Raudsepp et al., 2010; Tabart et al., 2011), and fatty acids (Ruiz del Castillio et al., 2004) that can be found mainly in fruit but also in leaves and buds. The main antioxidants present in blackcurrant fruit are phenols, anthocyanins and ascorbic acid (Bordonaba, Terry, 2008; Brennan, 2008; Brennan et al., 2008 b). Blackcurrant fruit, like other purple coloured fruits, is a rich source of anthocyanins. In blackcurrants the major anthocyanins are cyanidin-3-glucoside, cyanidin-3rutinoside, delphinidin-3-glucoside and delphinidin-3rutinosid (Lister et al., 2002; Brennan, 2008; Bordonaba et al., 2010). The major contributors to the high antioxidant activity of black currant fruit are phenols but ascorbic acid is also important (Lister et al., 2002). Ascorbic acid content in blackcurrant cultivars has been shown to be far higher than that reported for other fruits and also more stable due to the presence of anthocyanins and phenols (Hooper, Ayres, 1950; Miller, Rice-Evans, 1997). Ascorbic acid biosynthesis has been described in detail (Smirnoff, Wheeler, 2000; Hancock et al., 2007). Accumulation of ascorbic acid is the highest during berry expansion phase and the genotypic differences will persist in later ripening stages (Viola et al., 2000; Hancock et al., 2007). Ascorbic acid content is most significantly influenced by genotype (Франчук, 1971; Hancock et al., 2007; Pantelidis et al., 2007; Bordonaba, Terry, 2008), but climatic conditions (Hancock et al., 2007; Brennan, 2008) and latitude (Zheng et al., 2009 a) also have a remarkable influence on ascorbic acid accumulation, and individual genotypes respond differently to microclimatic conditions of a particular location (Zheng et al., 2009 b). Besides bioactive compounds, other quality characteristics such as soluble solids, sugar and acids content and their ratio are important. The ratio between sugar and acids in berries can act as an important indicator of fruit taste and quality (Bordonaba, Terry, 2008) being especially important when fruit is produced for fresh consumption. Overproduction of blackcurrant fruit and low retail prices in Europe at the turn of the century triggered the need for changes in aims of breeding programs and more attention is currently being paid to fruit quality and content of potentially health beneficial compounds (Brennan et al., 2008 b; Pluta et al., 2008). Another important quality attribute is fruit size, which is a genotype specific trait. When new or introduced cultivars are evaluated, it is important to assess their quality characteristics such as berry size, soluble solids, acid, sugar and ascorbic acid content, sugar to acid ratio as well as the correlations between these characteristics and the influence of weather conditions and microclimate on the formation of these qualities. Biochemical composition of blackcurrant fruit 
and influence of environmental factors on fruit quality of nine genotypes were assessed during five consecutive years (2006-2010) at Polli Horticultural Research Centre of theEstonian University of Life Sciences. The study included three genotypes ('Almo', 'Asker' and 'Karri') from our breeding program and six genotypes widely cultivated in Estonia and other countries: 'Ben Alder' (Scotland), 'Intercontinental', 'Titania', 'Öjebyn' (Sweden), 'Pamjati Vavilova' (Belarus) and 'Zagadka' (Russia).

\section{Materials and methods}

Experimental plot and conditions. The experiment was carried out during 2006-2010 at Polli Horticultural Research Centre of the Estonian University of Life Sciences, Institute of Agricultural and Environmental Sciences. Three new genotypes ('Karri', 'Almo' and 'Asker') from our own breeding program and six introduced cultivars ('Öjebyn', 'Zagadka', 'Ben Nevis', 'Intercontinental', 'Pamyati Vavilova' and 'Titania') were assessed in five consecutive years. The cultivar evaluation plot in South-Estonia, Polli (58 $7^{\circ} 26^{\prime \prime} \mathrm{N}, 2^{\circ} 32^{\prime} 43^{\prime \prime}$ E) was established in spring 2003 with one-year-old plants at a distance of $0.8 \mathrm{~m}$ in the row and $3.0 \mathrm{~m}$ between rows. Rows were mulched with black plastic and the space in between rows covered with grass and mowed four times during the summer period. Each spring, complex fertilizer "Cropcare 6-14-23" ("Kemira OY", Finland) at a rate of $300 \mathrm{~kg} \mathrm{ha}^{-1}$ was applied along the rows. No pesticides were used. The plantation was set up on a medium heavy loamy soil with a rather good drought resistance; therefore, no irrigation system was used.

Weather conditions. The data of average, maximum and minimum temperature and precipitation in June and July of testing years are given in Table 1. The summer of 2006 was very unfavourable for the growth of the plants and yield formation, June being dry and July especially dry with very high temperatures, the maximum reaching $37^{\circ} \mathrm{C}$ in the first half of the month. The amplitude of day-night temperature was very big, minimum temperature was $7^{\circ} \mathrm{C}$. Average temperatures in July of 2007, 2008 and 2009 were very similar and remained in range of long-term average $\left(16.7^{\circ} \mathrm{C}\right)$. The amplitude of day-night temperature was smaller in July 2007. Precipitation was low in June 2007, somewhat less than long-term average in July 2007 and 2008 and over long-term average in June 2008, 2009 and 2010 and in July 2009 and 2010. It was mostly rainy in June and July 2009. Average temperature throughout the testing years was the highest in July 2010, but the maximum was as low like in 2006. The amplitude of day-night temperatures in 2010 was as small as in 2006, 2008 and 2009.

Table 1. Average temperatures, minimum-maximum temperatures and sum of precipitation in June and July of the test years and relevant average values for the last 86-year period

\begin{tabular}{ccccccccc}
\hline \multirow{2}{*}{ Year } & \multicolumn{3}{c}{ Temperatures ${ }^{\circ} \mathrm{C}$ in June } & \multicolumn{3}{c}{ Temperatures ${ }^{\circ} \mathrm{C}$ in July } & \multicolumn{2}{c}{ Precipitation mm } \\
\cline { 2 - 9 } & average & maximum & minimum & average & maximum & minimum & in June & in July \\
\hline 2006 & 17.0 & 32.0 & 1.5 & 20.2 & 37.0 & 7.0 & 28.3 & 13.4 \\
2007 & 15.9 & 26.9 & 3.1 & 16.4 & 20.1 & 14.2 & 46.0 & 81.4 \\
2008 & 13.3 & 25.6 & 2.0 & 16.0 & 27.5 & 5.6 & 127.6 & 77.6 \\
2009 & 13.6 & 28.6 & 0.4 & 16.6 & 28.9 & 2.3 & 148.8 & 120.8 \\
2010 & 14.1 & 26.9 & 1.6 & 21.4 & 32.7 & 12.9 & 84.2 & 92.8 \\
\hline Average of years & 14.4 & & & \multirow{2}{*}{16.7} & & & \multirow{2}{*}{67.0} & 81.0 \\
$(1922-2008)$ & & & & & & &
\end{tabular}

Plant material and analytical methods. The study involved two new cultivars from the Polli breeding program released in 2008, one genotype registered in 2010, and six widely grown cultivars in Estonia and Europe. Three bushes per genotype, each bush as a replication, were included. The beginning of berry ripening was determined among the test bushes. One sample of $500 \mathrm{~g}$ of fully ripe berries per cultivar was collected in the middle of the harvesting season from each plots. In all times samples were collected at 10-11 before noon. The representative samples were prepared from the field samples, $200 \mathrm{~g}$ of fruit was homogenized using a kitchen blender and analysed on the same day for sugar, soluble solids and ascorbic acid contents. Soluble solids content in the homogenized samples was recorded using a refractometer ("Abbe WYA-1S", "Optic Ivymen System", Spain) at $20^{\circ} \mathrm{C}$; organic acids were determined by titration with $0.1 \mathrm{NaOH}$. Ascorbic acid was determined using the modified Tillman's method. Ascorbic acid was titrated with 2,6-dichloroindophenol under acid conditions (Плешков, 1968). The ferricyanide method was used for sugar content analysis (Туркин, Широков, 1960). The results are expressed in mg per $100 \mathrm{~g}$ of fresh fruit. The average weight of fruit was determined by weighing 20 fruit per sample.

Statistical analysis. The data were statistically processed using a two-factor analysis of variance
$(A N O V A)$ and correlation analysis method at significance level $P<0.05$.

\section{Results and discussion}

Fruit ripening and weight. Fruit ripening was the earliest in 2007 but in that year, the differences in ripening dates among the genotypes were the largest during the trial period. Ripening was rather early also in 2008 but the differences among genotypes were not as large (Table 2). In 2009, ripening was the latest within the trial period. It was rather late also in 2006 and the differences among genotypes were not large. Fruit ripening dates varied from year to year. Although in 2007 the average temperatures in July were lower than in 2006, fruit ripening was the earliest throughout the trial period. Most likely, the relatively warm weather in June and small differences between day and night temperatures in July facilitated the early ripening of berries. Late ripening in 2009 was most likely the result of low night temperatures in July and, to some extent, the abundant rainfall in June and July might have had effect. On average over the five years, the differences between genotypes in respect of fruit ripening were rather small. Cultivar 'Intercontinental' was the earliest, followed by 'Pamjati Vavilova' with fruits ripening almost simultaneously. Cultivars 'Almo', 'Asker', 'Karri' and 'Zagadka' ripened somewhat later and the latest were 'Ben Alder', 'Titania' and 'Öjebyn'. 
Table 2. Beginning of fruit ripening of blackcurrant genotypes evaluated in 2006-2010

\begin{tabular}{|c|c|c|c|c|c|}
\hline \multirow{2}{*}{ Genotype } & \multicolumn{5}{|c|}{ Beginning of fruit ripening } \\
\hline & 2006 & 2007 & 2008 & 2009 & 2010 \\
\hline 'Almo' & 2207 & 0807 & 1607 & 2807 & 2107 \\
\hline ‘Asker’ & 2507 & 0907 & 1607 & 2707 & 2007 \\
\hline 'Ben Alder' & 2607 & 1307 & 1807 & 2507 & 2307 \\
\hline 'Intercontinental' & 2207 & 0907 & 1607 & 2307 & 1707 \\
\hline 'Karri' & 2207 & 1107 & 1407 & 2807 & 2107 \\
\hline 'Pamjati Vavilova' & 2207 & 0607 & 1507 & 2507 & 2107 \\
\hline 'Zagadka' & 2207 & 1007 & 1507 & 2507 & 2107 \\
\hline 'Titania' & 2507 & 1307 & 1807 & 2707 & 2107 \\
\hline ‘Öjebyn’ & 2507 & 1207 & 1507 & 2807 & 2307 \\
\hline
\end{tabular}

On average of the genotypes, the fruits were the largest in 2010 and the smallest in 2008. In 2006, 2007, 2009 fruit size remained at the same level as average of the years (Table 3 ). On average the fruits of 'Intercontinental' were the largest; followed by 'Karri' with rather large fruits as well. In 2006 and 2008, average fruit weight of 'Karri' exceeded that of 'Intercontinental'. Cultivar 'Almo' has somewhat smaller fruit. Among the assessed genotypes the fruit of 'Öjebyn' was the smallest. Fruit size in blackcurrant is considered to be under polygenic control, and quantitative trait loci (QTLs) linked to fruit size have been identified by Brennan et al. (2008 a). In our trial, the cultivar 'Intercontinental' had the largest fruit. 'Karri' has also large berries while in some years they do not exceed the average. In all years, fruit weight of these two cultivars was higher than that of others, only in 2008 and 2009 when drop off of flowers due to spring frost damage was abundant, the late flowering cultivars such as 'Ben Alder' and 'Titania' had an advantage. Genotypes responded differently to environmental influences, for instance fruit weight of 'Asker', 'Zagadka' and 'Öjebyn' did not vary much along the trial period while the variation of fruit weight of 'Intercontinental' along the years was significant, in 2008 it was $1.1 \mathrm{~g}$ and in 2010 twice as high (2.2 g). Studies conducted elsewhere also confirm that fruit sizes are highly affected by environmental factors, although rankings between genotypes tend to remain constant (Brennan et al., 2008 a). In our study as well, there was a positive correlation $(r=0.77)$ between fruit weight and average temperature in July.

Table 3. Average fruit weight of blackcurrant genotypes in 2006-2010

\begin{tabular}{ccccccc}
\hline \multirow{2}{*}{ Genotype } & \multicolumn{7}{c}{ Average fruit weight g } & \multirow{2}{*}{ Mean } \\
\cline { 2 - 5 } & 2006 & 2007 & 2008 & 2009 & 2010 & $1.3 \pm 0.18$ \\
'Almo' & $1.2 \mathrm{c}$ & $1.2 \mathrm{c}$ & $1.2 \mathrm{ab}$ & $1.6 \mathrm{a}$ & $1.4 \mathrm{c}$ & $1.1 \pm 0.12$ \\
'Asker' & $1.2 \mathrm{c}$ & $1.1 \mathrm{~cd}$ & $0.9 \mathrm{de}$ & $1.1 \mathrm{~cd}$ & $1.2 \mathrm{de}$ & $1.1 \pm 0.23$ \\
'Ben Alder' & $1.0 \mathrm{ef}$ & $0.9 \mathrm{e}$ & $1.0 \mathrm{~cd}$ & $1.5 \mathrm{ab}$ & $1.1 \mathrm{e}$ & $1.1 \pm 0.2 \mathrm{a}$ \\
'Intercontinental' & $1.5 \mathrm{~b}$ & $1.6 \mathrm{a}$ & $1.1 \mathrm{bc}$ & $1.4 \mathrm{~b}$ & $2.2 \mathrm{a}$ & $1.6 \pm 0.40$ \\
'Karri' & $1.7 \mathrm{a}$ & $1.5 \mathrm{ab}$ & $1.3 \mathrm{a}$ & $1.2 \mathrm{c}$ & $1.7 \mathrm{~b}$ & $1.5 \pm 0.23$ \\
'Pamjati Vavilova' & $1.2 \mathrm{c}$ & $1.0 \mathrm{de}$ & $0.8 \mathrm{ef}$ & $0.9 \mathrm{ef}$ & $1.2 \mathrm{de}$ & $1.0 \pm 0.18$ \\
'Zagadka' & $1.2 \mathrm{c}$ & $1.2 \mathrm{c}$ & $1.0 \mathrm{~cd}$ & $1.1 \mathrm{~cd}$ & $1.3 \mathrm{~d}$ & $1.2 \pm 0.11$ \\
'Titania' & $1.1 \mathrm{de}$ & $1.4 \mathrm{~b}$ & $1.3 \mathrm{a}$ & $1.0 \mathrm{de}$ & $1.3 \mathrm{~d}$ & $1.2 \pm 0.16$ \\
'Öjebyn' & $0.9 \mathrm{f}$ & $1.1 \mathrm{~cd}$ & $0.8 \mathrm{ef}$ & $0.8 \mathrm{f}$ & $1.1 \mathrm{e}$ & $0.9 \pm 0.15$ \\
\hline Average of genotypes & 1.2 & 1.2 & 1.0 & 1.2 & 1.4 & 1.2 \\
\hline
\end{tabular}

Note. Means followed by the same letter within columns do not differ a $p<0.05$ level of significance; $\mathrm{LSD}_{0.05}$ variant $=0.13, \mathrm{LSD}_{0.05}$ year $=0.04, \mathrm{LSD}_{0.05}$ genotype $=0.06$

Ascorbic acid. Average ascorbic acid (AsA) content among genotypes was quite similar along the trial period being the highest in 2007, 2008, 2009 and the lowest in 2010 (Table 4). In all years, the AsA content was the highest in cultivar 'Asker', with the highest content in 2010 and the lowest in 2006. Cultivars 'Ben Alder', 'Intercontinental' and 'Pamjati Vavilova' revealed also rather high levels of ascorbic acid. The smallest amounts among the tested genotypes were found in fruit of cultivar 'Almo'. Relatively small variations in AsA content over the years were observed in fruit of 'Almo', 'Karri', 'Pamjati Vavilova' and 'Titania', with year 2010 being an exception when these cultivars had very low ascorbic acid content. On the contrary, in 2010 ascorbic acid content was high in cultivars 'Zagadka' and 'Öjebyn' that had rather modest contents in previous years. Variation in ascorbic acid content over the years was significant in 'Ben Alder, rather big differences in AsA levels over the years were observed also in cultivars 'Zagadka', 'Öjebyn' and 'Intercontinental'.

Soluble solids in juice. Average soluble solids content ( ${ }^{\circ}$ Brix) was the highest in 2010 and relatively high in 2006 although it was significantly lower than the average of 2010 . $^{\circ}$ Brix was the lowest in 2007 (Table 5). The differences in soluble solids content between years were the smallest in cultivars 'Zagadka' and 'Asker' and the highest in 'Intercontinental', 'Karri' and 'Pamjati Vavilova'. In 'Intercontinental' soluble solids content was significantly higher than in other cultivars, being followed by 'Titania', 'Almo', 'Öjebyn' and 'Karri'. The lowest ${ }^{\circ}$ Brix level was detected in 'Pamjati Vavilova'.

Titratable acids. The fruit contained the highest amount of organic acids in 2010; the content of acids was the lowest in 2007 and 2008. In 2006 and 2009, the content of organic acids was significantly lower than in 2010 (Table 6). The highest amounts of organic acid were found in fruit of cultivars 'Ben Alder', 'Intercontinental' and 'Titania' and the lowest amounts in cultivar 'Karri'. The differences in organic acid content over the years were the smallest in 'Zagadka', and rather small in cultivars 'Almo', 'Ben Alder', 'Karri' and 'Öjebyn'. The variation was largest in cultivars 'Intercontinental' and 'Pamjati Vavilova'. 
Table 4. Ascorbic acid content of blackcurrant fruit in genotypes tested in 2006-2010

\begin{tabular}{ccccccc}
\hline \multirow{2}{*}{ Genotype } & \multicolumn{4}{c}{ Ascorbic acid content mg $100 \mathrm{~g}^{-1}$ fresh weight } & \multirow{2}{*}{ Mean } \\
\cline { 2 - 6 } & 2006 & 2007 & 2008 & 2009 & 2010 & $105.6 \pm 18.19$ \\
'Almo' & $116 \mathrm{f}$ & $124 \mathrm{~g}$ & $106 \mathrm{~g}$ & $106 \mathrm{~h}$ & $76 \mathrm{~g}$ & $220.2 \pm 13.77$ \\
'Asker' & $209 \mathrm{a}$ & $214 \mathrm{a}$ & $223 \mathrm{a}$ & $212 \mathrm{a}$ & $243 \mathrm{a}$ & $143.2 \pm 48.6$ \\
'Ben Alder' & $113 \mathrm{f}$ & $145 \mathrm{e}$ & $213 \mathrm{~b}$ & $160 \mathrm{c}$ & $85 \mathrm{ef}$ & $147.0 \pm 37.52$ \\
'Intercontinental' & $139 \mathrm{c}$ & $183 \mathrm{~b}$ & $150 \mathrm{~d}$ & $175 \mathrm{~b}$ & $88 \mathrm{e}$ & $123.2 \pm 22.39$ \\
'Karri' & $132 \mathrm{~d}$ & $136 \mathrm{f}$ & $126 \mathrm{e}$ & $138 \mathrm{f}$ & $84 \mathrm{f}$ & $145.2 \pm 25.96$ \\
'Pamjati Vavilova' & $164 \mathrm{~b}$ & $160 \mathrm{c}$ & $158 \mathrm{c}$ & $143 \mathrm{e}$ & $101 \mathrm{~d}$ & $135.4 \pm 47.59$ \\
'Zagadka' & $104 \mathrm{~g}$ & $134 \mathrm{f}$ & $120 \mathrm{f}$ & $111 \mathrm{~g}$ & $208 \mathrm{~b}$ & $129.4 \pm 26.76$ \\
'Titania' & $141 \mathrm{c}$ & $149 \mathrm{~d}$ & $124 \mathrm{e}$ & $148 \mathrm{~d}$ & $85 \mathrm{ef}$ & $125.6 \pm 38.74$ \\
'Öjebyn' & $124 \mathrm{e}$ & $87 \mathrm{~h}$ & $96 \mathrm{~h}$ & $136 \mathrm{f}$ & $185 \mathrm{c}$ & \\
\hline Average of genotype & 138 & 148 & 146.2 & 147.7 & 128.3 & \\
\hline
\end{tabular}

Note. Means followed by the same letter within columns do not differ at $p<0.05$ level of significance, $\operatorname{LSD}_{0.05}$ variant $=3.43$, $\mathrm{LSD}_{0.05}$ year $=1.15, \mathrm{LSD}_{0.05}$ genotype $=1.54$.

Table 5. Soluble solids content ( ${ }^{\circ}$ Brix) in blackcurrant fruit of genotypes tested in 2006-2010

\begin{tabular}{|c|c|c|c|c|c|c|}
\hline \multirow{2}{*}{ Genotype } & \multicolumn{5}{|c|}{ Soluble solids ( ${ }^{\circ}$ Brix) } & \multirow{2}{*}{ Mean } \\
\hline & 2006 & 2007 & 2008 & 2009 & 2010 & \\
\hline 'Almo' & $17.3 \mathrm{c}$ & $15.5 \mathrm{~cd}$ & $17.6 \mathrm{c}$ & $17.4 \mathrm{~b}$ & $18.3 \mathrm{bc}$ & $17.2 \pm 0.9$ \\
\hline 'Asker' & $16.3 \mathrm{e}$ & $16.6 \mathrm{~b}$ & $14.9 \mathrm{f}$ & $16.2 \mathrm{c}$ & $16.6 \mathrm{e}$ & $16.1 \pm 0.6$ \\
\hline 'Ben Alder' & $15.7 \mathrm{f}$ & $13.7 \mathrm{f}$ & $15.5 \mathrm{e}$ & $15.6 \mathrm{~d}$ & $15.5 \mathrm{f}$ & $15.2 \pm 0.7$ \\
\hline 'Intercontinental' & $18.6 \mathrm{a}$ & $17.4 \mathrm{a}$ & $19.0 \mathrm{a}$ & $16.4 \mathrm{c}$ & $19.0 \mathrm{a}$ & $18.1 \pm 1.0$ \\
\hline 'Karri' & $17.1 \mathrm{c}$ & $15.5 \mathrm{~cd}$ & $16.5 \mathrm{~d}$ & $17.7 \mathrm{ab}$ & $18.4 \mathrm{~b}$ & $17.0 \pm 1.0$ \\
\hline 'Pamjati Vavilova' & $16.4 \mathrm{e}$ & $15.2 \mathrm{~d}$ & $14.7 \mathrm{f}$ & $13.9 \mathrm{e}$ & $16.4 \mathrm{e}$ & $15.3 \pm 1.0$ \\
\hline 'Zagadka' & $16.6 \mathrm{e}$ & $15.8 \mathrm{c}$ & $16.4 \mathrm{~d}$ & $16.3 \mathrm{c}$ & $15.0 \mathrm{~g}$ & $16.0 \pm 0.6$ \\
\hline 'Titania' & $16 \mathrm{ef}$ & $17.1 \mathrm{a}$ & $18.2 \mathrm{~b}$ & $17.9 \mathrm{a}$ & $17.3 \mathrm{~d}$ & $17.3 \pm 0.8$ \\
\hline 'Öjebyn' & $17.8 \mathrm{~b}$ & $17.5 \mathrm{a}$ & $15.6 \mathrm{e}$ & $16.4 \mathrm{c}$ & $17.9 \mathrm{c}$ & $17.2 \pm 0.9$ \\
\hline Average of genotype & 16.9 & 16.0 & 16.5 & 16.4 & 17.2 & \\
\hline
\end{tabular}

Note. Means followed by the same letter within columns do not differ at $p<0.05$ level of significance; $\operatorname{LSD}_{0.05}$ variant $=0.46$, $\mathrm{LSD}_{0.05}$ years $=0.15, \mathrm{LSD}_{0.05}$ genotype $=0.27$.

Table 6. Titratable acids in blackcurrant fruit of genotypes tested in 2006-2010

\begin{tabular}{ccccccc}
\hline \multirow{2}{*}{ Genotype } & \multicolumn{7}{c}{ Titratable acids \% } & \multirow{2}{*}{ Mean } \\
\cline { 2 - 6 } & 2006 & 2007 & 2008 & 2009 & 2010 & $2.7 \pm 0.3$ \\
'Almo' & $2.8 \mathrm{~b}$ & $2.3 \mathrm{bc}$ & $2.6 \mathrm{~b}$ & $2.9 \mathrm{ab}$ & $3.1 \mathrm{~cd}$ & $2.7 \pm 0.5$ \\
'Asker' & $2.6 \mathrm{~b}$ & $2.3 \mathrm{bc}$ & $2.2 \mathrm{bc}$ & $2.7 \mathrm{~b}$ & $3.6 \mathrm{bc}$ & $3.2 \pm 0.3$ \\
'Ben Alder' & $3.3 \mathrm{a}$ & $3.2 \mathrm{a}$ & $3.0 \mathrm{ab}$ & $2.9 \mathrm{ab}$ & $3.8 \mathrm{bc}$ & $3.2 \pm 0.6$ \\
'Intercontinental' & $2.9 \mathrm{ab}$ & $2.9 \mathrm{ab}$ & $3.1 \mathrm{a}$ & $2.7 \mathrm{~b}$ & $4.4 \mathrm{a}$ & $2.4 \pm 0.3$ \\
'Karri' & $2.4 \mathrm{~b}$ & $2.1 \mathrm{c}$ & $2.1 \mathrm{c}$ & $2.4 \mathrm{~b}$ & $2.9 \mathrm{~d}$ & $2.8 \pm 0.6$ \\
'Pamjati Vavilova' & $2.7 \mathrm{~b}$ & $2.3 \mathrm{~b}$ & $2.5 \mathrm{bc}$ & $2.7 \mathrm{~b}$ & $3.9 \mathrm{~b}$ & $2.9 \pm 0.1$ \\
'Zagadka' & $2.9 \mathrm{ab}$ & $2.8 \mathrm{ab}$ & $2.7 \mathrm{ab}$ & $3.0 \mathrm{ab}$ & $2.9 \mathrm{~d}$ & $3.2 \pm 0.5$ \\
'Titania' & $3.1 \mathrm{ab}$ & $2.9 \mathrm{ab}$ & $2.8 \mathrm{ab}$ & $3.2 \mathrm{a}$ & $4.2 \mathrm{ab}$ & $2.8 \pm 0.3$ \\
'Öjebyn' & $2.6 \mathrm{~b}$ & $2.6 \mathrm{~b}$ & $2.7 \mathrm{ab}$ & $2.6 \mathrm{~b}$ & $3.4 \mathrm{c}$ &
\end{tabular}

Note. Means followed by the same letter within columns do not differ at $p<0.05$ level of significance; $\operatorname{LSD}_{0.05}$ variant $=0.45$, $\mathrm{LSD}_{0.05}$ years $=0.15, \mathrm{LSD}_{0.05}$ genotype $=0.20$.

Sugar content and sugar to acid ratio. On average, sugar content in fruit was the highest in 2006 and the lowest in 2007 (Table 7). On average over the years, sugar content was the highest in 'Titania' and only slightly lower in 'Karri'. In most of the cultivars the differences in sugar content among the years were large, especially in cultivars 'Titania', 'Pamjati Vavilova' and 'Intercontinental', the variation between years was somewhat smaller in 'Karri' and 'Zagadka'.

There is a relatively low amount of sucrose in blackcurrant fruit and accumulation of sugars differs among years. For example, in 2010 there was no sucrose in 'Almo', 'Karri' and 'Öjebyn' and very small amounts were found in other genotypes (Table 8).
Sucrose content was the highest in 2006. From the genotypes, the richest in sucrose were 'Titania' and 'Intercontinental' and 'Ben Alder' was the poorest. The differences in sucrose content in different years were the largest with 'Almo', 'Asker' and 'Titania' and the smallest in 'Karri'. The average sugar to acid ratio was the best in 2006 and worst in 2010 (Table 9). Over the years, the sugar to acid ratio was the highest in 'Karri' and the lowest in 'Ben Alder'. Among genotypes, the variation of sugar acid ratio over the years was largest in 'Titania', 'Pamjati Vavilova' and 'Intercontinental' and the smallest in 'Karri' and 'Zagadka'. 
Table 7. Sugar content in blackcurrant fruit of genotypes tested in 2006-2010

\begin{tabular}{ccccccc}
\hline \multirow{2}{*}{ Genotype } & \multicolumn{5}{c}{ Sugar \% } & \multirow{2}{*}{ Mean } \\
\cline { 2 - 5 } & 2006 & 2007 & 2008 & 2009 & 2010 & $8.4 \pm 1.4$ \\
'Almo' & $10.7 \mathrm{~d}$ & $7.0 \mathrm{c}$ & $9.0 \mathrm{c}$ & $8.4 \mathrm{c}$ & $7.0 \mathrm{e}$ & $8.0 \pm 1.7$ \\
'Asker' & $10.7 \mathrm{~d}$ & $6.2 \mathrm{e}$ & $6.0 \mathrm{~g}$ & $8.4 \mathrm{c}$ & $8.5 \mathrm{~b}$ & $6.5 \pm 1.6$ \\
'Ben Alder' & $9.5 \mathrm{~g}$ & $5.1 \mathrm{f}$ & $5.1 \mathrm{~h}$ & $6.9 \mathrm{e}$ & $5.9 \mathrm{~h}$ & $8.4 \pm 1.9$ \\
'Intercontinental' & $11.6 \mathrm{c}$ & $7.6 \mathrm{a}$ & $9.6 \mathrm{~b}$ & $6.9 \mathrm{e}$ & $6.6 \mathrm{~g}$ & $8.8 \pm 0.9$ \\
'Karri' & $10.3 \mathrm{f}$ & $7.5 \mathrm{a}$ & $8.6 \mathrm{~d}$ & $8.4 \mathrm{c}$ & $9.4 \mathrm{a}$ & $8.0 \pm 1.9$ \\
'Pamjati Vavilova' & $11.9 \mathrm{~b}$ & $7.5 \mathrm{a}$ & $7.3 \mathrm{e}$ & $6.6 \mathrm{f}$ & $7.6 \mathrm{~d}$ & $9.0 \pm 2.1$ \\
'Zagadka' & $9.5 \mathrm{~g}$ & $7.2 \mathrm{~b}$ & $7.0 \mathrm{f}$ & $9.3 \mathrm{a}$ & $7.0 \mathrm{e}$ & $8.2 \pm 1.3$ \\
'Titania' & $12.6 \mathrm{a}$ & $7.0 \mathrm{c}$ & $10.0 \mathrm{a}$ & $8.7 \mathrm{~b}$ & $6.8 \mathrm{f}$ & $7.9 \mathrm{c}$ \\
'Öjebyn' & $10.5 \mathrm{e}$ & $6.8 \mathrm{~d}$ & $8.5 \mathrm{~d}$ & $7.5 \mathrm{~d}$ & 7.9 & \\
\hline Average of genotypes & 10.8 & 6.9 & 7.9 & 7.9 & 7.4 & \\
\hline
\end{tabular}

Note. Means followed by the same letter within columns do not differ at $p<0.05$ level of significance; $\operatorname{LSD}_{0.05}$ variant $=0.18$, $\mathrm{LSD}_{0.05}$ years $=0.06, \mathrm{LSD}_{0.05}$ genotype $=0.08$.

Table 8. Sucrose content in blackcurrant fruit of genotypes tested in 2006-2010

\begin{tabular}{ccccccc}
\hline \multirow{2}{*}{ Genotype } & \multicolumn{5}{c}{ Sucrose \% } & \multirow{2}{*}{ Mean } \\
\cline { 2 - 6 } & 2006 & 2007 & 2008 & 2009 & 2010 & $1.26 \pm 1.03$ \\
'Almo' & $2.7 \mathrm{~b}$ & $0.2 \mathrm{c}$ & $2.0 \mathrm{a}$ & $1.4 \mathrm{~d}$ & $0.0 \mathrm{f}$ & $1.06 \pm 1.08$ \\
'Asker' & $3.0 \mathrm{a}$ & $0.2 \mathrm{c}$ & $0.2 \mathrm{~d}$ & $0.4 \mathrm{f}$ & $1.5 \mathrm{a}$ & $0.60 \pm 0.70$ \\
'Ben Alder' & $2.0 \mathrm{~d}$ & $0.2 \mathrm{c}$ & $0.2 \mathrm{~d}$ & $0.3 \mathrm{f}$ & $0.3 \mathrm{e}$ & $1.42 \pm 0.62$ \\
'Intercontinental' & $2.2 \mathrm{c}$ & $0.8 \mathrm{~b}$ & $1.9 \mathrm{a}$ & $1.6 \mathrm{c}$ & $0.6 \mathrm{~cd}$ & $0.82 \pm 0.49$ \\
'Karri' & $0.9 \mathrm{f}$ & $1.2 \mathrm{a}$ & $1.4 \mathrm{~b}$ & $0.6 \mathrm{e}$ & $0.0 \mathrm{f}$ & $0.88 \pm 0.72$ \\
'Pamjati Vavilova' & $2.1 \mathrm{~cd}$ & $1.3 \mathrm{a}$ & $0.2 \mathrm{~d}$ & $0.3 \mathrm{f}$ & $0.5 \mathrm{~d}$ & $1.16 \pm 0.82$ \\
'Zagadka' & $0.9 \mathrm{f}$ & $1.2 \mathrm{a}$ & $0.3 \mathrm{~d}$ & $2.7 \mathrm{a}$ & $0.7 \mathrm{c}$ & $1.50 \pm 0.92$ \\
'Titania' & $3.0 \mathrm{a}$ & $0.8 \mathrm{~b}$ & $0.5 \mathrm{c}$ & $2.1 \mathrm{~b}$ & $1.1 \mathrm{~b}$ & $0.70 \pm 0.64$ \\
'Öjebyn' & $1.4 \mathrm{c}$ & $0.0 \mathrm{~d}$ & $1.5 \mathrm{~b}$ & $0.7 \mathrm{e}$ & $0.0 \mathrm{f}$ & 0.5 \\
\hline Average of genotypes & 2.0 & 0.7 & 0.9 & 1.1 & 0.1
\end{tabular}

Note. Means followed by the same letter within columns do not differ at $p<0.05$ level of significance; $\operatorname{LSD}_{0.05}$ variant $=0.17$, $\mathrm{LSD}_{0.05}$ years $=0.06, \mathrm{LSD}_{0.05}$ genotype $=0.08$.

Table 9. Sugar to acid ratio in blackcurrant fruit of genotypes tested in 2006-2010

\begin{tabular}{|c|c|c|c|c|c|c|}
\hline \multirow{2}{*}{ Genotype } & \multicolumn{5}{|c|}{ Sugar: acid } & \multirow{2}{*}{ Mean } \\
\hline & 2006 & 2007 & 2008 & 2009 & 2010 & \\
\hline 'Almo' & $3.8 \mathrm{e}$ & $3.0 \mathrm{c}$ & $3.5 \mathrm{~b}$ & $2.9 \mathrm{c}$ & $2.3 \mathrm{~b}$ & $3.1 \pm 0.52$ \\
\hline 'Asker' & $4.2 \mathrm{c}$ & $2.7 \mathrm{~d}$ & $2.8 \mathrm{e}$ & $3.1 \mathrm{~b}$ & $2.4 \mathrm{~b}$ & $3.0 \pm 0.62$ \\
\hline 'Ben Alder' & $2.8 \mathrm{~g}$ & $1.6 \mathrm{f}$ & $1.7 \mathrm{~g}$ & $2.4 \mathrm{e}$ & $1.6 \mathrm{~d}$ & $2.0 \pm 0.49$ \\
\hline 'Intercontinental' & $4.4 \mathrm{~d}$ & $2.6 \mathrm{~d}$ & $3.1 \mathrm{~cd}$ & $2.6 \mathrm{~d}$ & $1.5 \mathrm{~d}$ & $2.8 \pm 0.81$ \\
\hline 'Karri' & $4.2 \mathrm{c}$ & $3.7 \mathrm{a}$ & $4.0 \mathrm{a}$ & $3.5 \mathrm{a}$ & $3.2 \mathrm{a}$ & $3.7 \pm 0.35$ \\
\hline 'Pamjati Vavilova' & $4.4 \mathrm{~b}$ & $3.3 \mathrm{~b}$ & $3.0 \mathrm{~d}$ & $2.4 \mathrm{e}$ & $1.9 \mathrm{c}$ & $3.0 \pm 0.85$ \\
\hline 'Zagadka' & $3.2 \mathrm{f}$ & $2.6 \mathrm{~d}$ & $2.6 \mathrm{f}$ & $3.1 \mathrm{~b}$ & $2.4 \mathrm{~b}$ & $2.8 \pm 0.31$ \\
\hline 'Titania' & $4.1 \mathrm{~cd}$ & $2.4 \mathrm{e}$ & $3.5 \mathrm{~b}$ & $2.8 \mathrm{c}$ & $1.6 \mathrm{~d}$ & $2.9 \pm 0.87$ \\
\hline ‘Öjebyn’ & $4.7 \mathrm{a}$ & $2.6 \mathrm{~d}$ & $3.2 \mathrm{c}$ & $2.9 \mathrm{c}$ & $2.3 \mathrm{~b}$ & $3.1 \pm 0.84$ \\
\hline
\end{tabular}

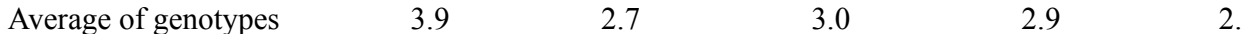

Note. Means followed by the same letter within columns do not differ at $p<0.05$ level of significance; $\operatorname{LSD}_{0.05}$ variant $=0.12$, $\mathrm{LSD}_{0.05}$ years $=0.04, \mathrm{LSD}_{0.05}$ genotype $=0.05$.

Influence of average precipitation and average temperature in July on fruit weight and nutritional content. The experiment revealed a strong positive correlation between average temperatures in July and fruit weight, total soluble solids content and acidity, with correlation coefficients $r=0.77, r=0.90$ and $r=0.82$, respectively (Table 10). Temperatures in July had less effect on sugar content $(r=0.40)$. Average temperature in July was strongly negatively correlated with ascorbic acid content, $r=-0.95$, while the response of genotypes varied. July temperatures did not influence fruit weight of cultivars 'Almo', 'Ben Alder' and 'Titania' and, in contrast to other genotypes, had a weak and positive effect on ascorbic acid content of cultivars 'Asker' and 'Zagadka'.
Precipitation in July was negatively correlated with total sugar content and sugar to acid ratio, with correlation coefficients $r=-0.82$ and $r=-0.75$ respectively. For the cultivar 'Zagadka' both of these correlations were relatively weak, $r=-0.29$ and $r=-0.36$ respectively.

The study revealed a positive correlation between average fruit weight, total soluble solids and acid content, $r=0.53$ and $r=0.85$ respectively. Negative correlations were revealed between average fruit weight and ascorbic acid content $(r=-0.74)$; and between ascorbic acid content and total soluble solids and acid content, $r=0.92$ and $r=0.91$ respectively. Total sugar and sucrose content correlated positively with sugar to acid ratio, $r=0.96$ and $r=0.88$ respectively. 
Table 10. Correlation between average temperature, sum of precipitation, fruit weight, ascorbic acid content, juice soluble solids ( ${ }^{\circ}$ Brix) total sugar and sucrose content, acid and sugar to acid ratio

\begin{tabular}{|c|c|c|c|c|c|c|c|c|c|}
\hline & Temperature & Precipitation & Weight & Ascorbic acid & ${ }^{\circ}$ Brix & Sugar & Sucrose & Acid & Sugar: acid \\
\hline Temperature & 1 & & & & & & & & \\
\hline Precipitation & -0.377 & 1 & & & & & & & \\
\hline Weight & 0.766 & 0.136 & 1 & & & & & & \\
\hline Ascorbic acid & -0.953 & 0.238 & -0.736 & 1 & & & & & \\
\hline${ }^{\circ}$ Brix & 0.896 & -0.288 & 0.534 & -0.923 & 1 & & & & \\
\hline Sugar & 0.403 & -0.820 & -0.116 & -0.191 & 0.414 & 1 & & & \\
\hline Sucrose & 0.175 & -0.747 & -0.243 & 0.074 & 0.158 & 0.959 & 1 & & \\
\hline Acid & 0.820 & 0.177 & 0.852 & -0.909 & 0.806 & -0.124 & -0.348 & 1 & \\
\hline Sugar/acid & -0.064 & -0.751 & -0.490 & 0.287 & -0.058 & 0.878 & 0.957 & -0.583 & 1 \\
\hline
\end{tabular}

High ascorbic acid (vitamin C) content is a very important quality factor of blackcurrant (Hummer, Barney, 2002; Brennan, 2008 a). In our study, cultivar 'Asker' had high ascorbic acid content in all the years. Similarly to the results from the Polish study (Kawecki et al., 2006) AsA content in cultivar 'Titania' was relatively moderate, but in our trial 'Intercontinental' had remarkably higher AsA content compared with that found in the Lithuanian study (Sasnauskas et al., 2009). Our study revealed large differences in AsA content along the years in cultivar 'Intercontinental', while in cultivar 'Titania' there were only slight differences. Thus, the growing conditions and microclimate have a larger effect on AsA content in 'Intercontinental' than in 'Titania'. Some researchers suggest that, although ascorbic acid content depends on the genotype, significant environmental effects have been noted in the level of ascorbic acid (Hancock et al., 2007; Pedersen, 2008; Brennan, Graham, 2009; Hackett et al., 2010). Our study revealed a strong negative correlation $(r=-0.95)$ between average temperature in July and ascorbic acid content in the fruit. Similar correlation was reported from the trial conducted in Finland (Zheng et al., 2009 b). The genotypes responded differently, for cultivars 'Asker' and 'Zagadka' the correlation was positive and relatively weak, but in 'Intercontinental' it was strong and in 'Titania' moderate. Similarly to our findings, differences in responses of genotypes have been reported in trials conducted elsewhere. The current study revealed a strong negative correlation between ascorbic acid, soluble solids and organic acids content and berry weight with correlation coefficients $r=-0.92, r=-0.91$ and $r=-0.74$, respectively. Investigations carried out elsewhere have also stated that no correlation has been found between ascorbic acid content, soluble solids content or sugar level (Viola et al., 2000), similarly in our trial we did not find correlation between ascorbic acid and sugar content.

Sugar and acid content and sugar to acid ratio in blackcurrant and other fruits is essential in flavour formation (Bordonaba, Terry, 2008; 2009; Crespo et al., 2010). For example both cultivars 'Titania' and 'Karri' contain rather high levels of sugar but the first one has a lot of acids and the other not so much, therefore the sugar to acid ratio is much better in cultivar 'Karri'. Although soluble solids content and sugar to acid ratio depends largely on genotype, we found a strong positive correlation between temperatures in July and total soluble solids and acid contents. Similar results were reported from the Lithuanian study (Rubinskiene et al., 2006). In the Finnish trial the contents of fructose, glucose and citric acid of cultivar 'Melalahti' were not influenced by the weather conditions, whereas in 'Mortti' and 'Ola' these parameters correlated positively with average temperature in July (Zheng et al., 2009 b). In our study, there was a weak positive correlation $(r=0.40)$ between temperatures in July and sugar content of fruit and sugar to acid ratio. Precipitation in July had negative effect on average sugar and sucrose content of genotypes ( $r=-0.82$ and $r=0.75$, respectively) and on sugar acid ratio $(r=0.75)$, while the effect of precipitation on sugar content was relatively small for cultivars 'Zagadka' and 'Asker'.

\section{Conclusions}

1. Fruit weight and nutritional content of blackcurrant fruit depended primarily on the genotype but average temperatures in July correlated negatively with ascorbic acid content and positively with fruit weight, soluble solids content ( ${ }^{\circ}$ Brix) and organic acids content; amount of precipitation in July correlated negatively with sugars and sucrose content and sugar to acid ratio. Cultivar 'Asker' showed relatively high and stable ascorbic acid content.

2. Sugar content was high in 'Karri', 'Almo', 'Intercontinental' and 'Titania'. The last two contained high concentrations of acids as well, and the sugar to acid ratio in these was relatively low. Sugar to acid ratio was the best and most stable in low acid cultivar 'Karri'. The largest fruit was in cultivars 'Intercontinental' and 'Karri'.

3. The effect of weather conditions on nutritional content was relatively weak for the cultivar 'Zagadka'. The impact of weather conditions on nutritional content and berry weight was the largest for cultivar 'Intercontinental'.

\section{Acknowledgements}

We thank the Estonian Science Foundation (grant No. 7703) and Ministry of Education and Research (target financing project No. 1092711s06) for financial support.

Received 10072012 Accepted 03012013 


\section{References}

Bordonaba G. J., Terry L. A. 2008. Biochemical profiling and chemometric analysis of seventeen UK-grown blackcurrant cultivars. Journal of Agricultural and Food Chemistry, 56 (16): 7422-7430 http://dx.doi.org/10.1021/jf8009377

Bordonaba G. J., Terry L. A. 2009. Development of a glucose biosensor for rapid assessment of strawberry quality: relationship between biosensor response and fruit composition. Journal of Agricultural and Food Chemistry, 57 (18): 8220-8226 http://dx.doi.org/10.1021/jf901596w

Bordonaba G. J., Chope G. A., Terry L. A. 2010. Maximising blackcurrant anthocyanins: temporal changes during ripening and storage in different genotypes. Journal of Berry Research, 1 (1): 73-80

Brennan R. M. 2008. Currants and gooseberries. Temperate fruit crop breeding. Hancock J. F. (ed.). Berlin, Germany, p. $177-196$ http://dx.doi.org/10.1007/978-1-4020-6907-9 6

Brennan R., Jorgensen L., Hackett C., Woodhead M., Gordon S., Russell J. 2008 (a). The development of genetic linkage map of blackcurrant (Ribes nigrum L.) and identification of regions associated with key fruit quality and agronomic traits. Euphytica, 161 (1-2): 19-34 http://dx.doi.org/10.1007/s10681-007-9412-8

Brennan R. M., Stewart D., Russell J. 2008 (b). Developments and progress in Ribes breeding. Acta Horticulturae, 777: 49-53

Brennan R. M., Graham J. 2009. Improving fruit quality in Ribes and Rubus through breeding. Functional Plant Science and Biotechnology, 3 (1): 22-29

Crespo P., Bordonaba G. J., Terry L. A., Carlen C. 2010 Characterization of major taste and health-related compounds of four strawberry genotypes grown at different Swiss production sites. Food Chemistry, 122: 16-24 http://dx.doi.org/10.1016/j.foodchem.2010.02.010

Hackett C. A., Russell J., Jorgensen L., Gordon S. L., Brennan R. M. 2010. Multi-environmental QTL mapping in blackcurrant (Ribes nigrum L.) using mixed models. Theoretical and Applied Genetics, 121 (8): 1483-1488 http://dx.doi.org/10.1007/s00122-010-1404-8

Hancock R. D., Walker P. G, Pont S. D. A., Marquis N., Vivera S., Gordon S. L., Brennan R. M., Viola R. 2007. L-ascorbic acid accumulation in fruit of Ribes nigrum occurs by in situ biosynthesis via the L-galactose pathway. Functional Plant Biology, 34 (1): 1080-1091 http://dx.doi.org/10.1071/FP07221

Hooper F. C., Ayres A. D. 1950. The enzymatic degradation of ascorbic acid. Part 1. The inhibition of the enzymatic oxidation of ascorbic acid by substances occurring in black currants. Journal of the Science of Food and Agriculture, 1: 5-8 http://dx.doi.org/10.1002/jsfa.2740010104

Hummer K. E., Barney D. L. 2002. Currants. HortTechnology, 12 (3): $377-387$

Kawecki Z., Bieniek A., Kopytowski J., Šikšnianas T. 2006. Preliminary assessment of productivity and fruit quality of Lithuanian and Ukrainian cultivars of blackcurrant under the climatic conditions of Olsztyn. Journal of Fruit and Ornamental Plant Research, 14: 75-80

Lister C. E., Wilson P. E., Sutton K. H., Morris S. C. 2002. Understanding the health benefits of blackcurrants. Acta Horticulturae, 585: 443-449

Miller N. J., Rice-Evans C. A. 1997. The relative contributions of ascorbic acid and phenolic antioxidants to the total antioxidant activity of orange and apple fruit juices and blackcurrant drink. Food Chemistry, 60: 331-337 http://dx.doi.org/10.1016/S0308-8146(96)00339-1
Pantelidis G. E., Vasilakakis M., Manganaris G.A., Diamantidis G. 2007. Antioxidant capacity, phenol, anthocyanin and ascorbic acid contents in raspberries, blackberries, red currants, gooseberries and Cornelian cherries. Food Chemistry, 102: 777-783

http://dx.doi.org/10.1016/j.foodchem.2006.06.021

Pedersen H. L. 2008. Juice quality and yield capacity of black currant cultivars in Denmark. Acta Horticulturae, 777: 510-516

Pluta S., Madry W., Zurawicz E. 2008. General combining ability of selected blackcurrant (Ribes nigrum L.) genotypes in breeding for dessert quality fruit. Acta Horticulturae, 777: 57-62

Raudsepp P., Kaldmäe H., Kikas A., Libek A. V., Püssa T. 2010. Nutritional quality of berries and bioactive compounds in the leaves of black currant (Ribes nigrum L.) cultivars evaluated in Estonia. Journal of Berry Research, 1 (1): 53-59

Rubinskiene M., Viskelis P., Jasutiene I., Duchovskis P., Bobinas C. 2006. Changes in biologically active constituents during ripening in black currant. Journal of Fruit and Ornamental Plant Research, 16 (2): 237-246

Ruiz del Castillio M. L., Dobson G., Brennan R., Gordon S. 2004. Fatty acid content and juice characteristics in black currant (Ribes nigrum L.) genotypes. Journal of Agricultural and Food Chemistry, 52 (4): 948-952 http://dx.doi.org/10.1021/jf034950q

Sasnauskas A., Trajkovski V., Strautina S., Tikhonova O., Šikšnianas T., Rubinskienė M., Viškelis P., Lanauskas J., Valiuškaitė A., Rugienius R., Bobinas Č. 2009. Evaluation of blackcurrant cultivars and perspective hybrids in Lithuania. Agronomy Research, 7 (II): 737-743

Smirnoff N., Wheeler G. L. 2000. Ascorbic acid in plants: biosynthesis and function. Critical Reviews in Biochemistry and Molecular Biology, 35 (4): 291-314 http://dx.doi.org/10.1080/10409230008984166

Tabart J., Kevers C., Evers D., Dommes J. 2011. Ascorbic acid, phenolic acid, flavonoid, and carotenoid profiles of selected extracts from Ribes nigrum. Journal of Agricultural and Food Chemistry, 59 (9): 4763-4770 http://dx.doi.org/10.1021/jf104445c

Viola R., Brennan R. M., Davies H. V., Sommerville L. 2000. $\mathrm{L}$-ascorbic acid accumulation in berries of Ribes nigrum $\mathrm{L}$. The Journal of Horticultural Science and Biotechnology, 75 (4): 409-412

Zheng J., Kallio H., Yang B. 2009 (a). Effect of latitude and weather conditions on sugars, fruit acids and ascorbic acid in currant (Ribes sp.) cultivars. Journal of the Science of Food and Agriculture, 89 (12): 2011-2023 http://dx.doi.org/10.1002/jsfa.3682

Zheng J., Yang B., Tuomasjukka S., Ou S., Kallio H. 2009 (b). Effects of latitude and weather conditions on contents of sugars, fruit acids, and ascorbic acid in black currant (Ribes nigrum L.) juice. Journal of Agricultural and Food Chemistry, 57 (7): 2977-2987 http://dx.doi.org/10.1021/jf8034513

ФранчукЕ.П.1971.Наследованиесодержания аскорбиновой кислоты в гибридном потомстве черной смородины. Сборник научных работ ВНИИ Садоводства им. И. В. Мичурина / 15: 155-162 (in Russian)

Плешков В. П. 1968. Практикум по биохимий. Москва, c. 175-176 (in Russian)

Туркин В. А., Широков Е. П.1960. Технология хранения и переработка плодов и овощей. Москва, с. 149-156 (in Russian) 
ISSN 1392-3196 / e-ISSN 2335-8947

Zemdirbyste-Agriculture, vol. 100, No. 2 (2013), p. 167-174

DOI 10.13080/z-a.2013.100.021

\title{
Genotipas ir mikroklimato sąlygos turi įtakos juodojo serbento (Ribes nigrum L.) vaisių sunokimui bei kokybei
}

\author{
H. Kaldmäe, A. Kikas, L. Arus, A. V. Libek
}

Estijos gyvybės mokslų universiteto Žemès ūkio ir aplinkos mokslų instituto Polli sodininkystès ir daržininkystès tyrimų centras

\begin{abstract}
Santrauka
Juodojo serbento (Ribes nigrum L.) vaisiai yra vertinami dèl žmonių sveikatai labai naudingų maisto medžiagų. Tradiciškai didžioji dalis juodųjų serbentų produkcijos yra perdirbama, bet pastaraisiais metais vis daugiau jų vartojama šviežių. Vaisių kokybè - dydis ir mitybinè vertė-yra itin svarbūs desertinio tipo veislèms, todèl pastaruoju metu juodujų serbentų selekcijos programose šioms savybėms skiriama vis daugiau dèmesio. Tyrimai buvo atlikti 2006-2010 m. Estijos gyvybės mokslų universiteto Žemès ūkio ir aplinkos mokslų instituto Polli sodininkystės ir daržininkystės tyrimų centre. Tirta trijų vietinès selekcijos veislių ('Almo', 'Karri', 'Asker') ir šešių introdukuotų veislių: 'Ben Alder' (Škotija), 'Intercontinental', 'Titania', ‘Öjebyn' (Švedija), 'Pamjati Vavilova' (Baltarusija) bei 'Zagadka' (Rusija), vaisių kokybė. Vertinti šie rodikliai: vaisių nokimo dinamika, dydis, tirpių sausujų medžiagų ( ${ }^{\circ}$ Brix), cukraus, rūgščių ir vitamino C kiekis. Didžiausius vaisius užaugino veislių 'Intercontinental' ir 'Karri' juodieji serbentai. Veislès 'Titania' vaisiai turèjo didelị kiekị cukraus ir rūgščių, o veislès 'Karri' uogose buvo daug cukraus ir mažai rūgščių. Daugelio tirtų rodiklių atžvilgiu stabiliausios buvo veislès 'Karri' ir 'Zagadka', o veislẻ 'Asker' iš kitų išsiskyre stabiliai dideliu vitamino C kiekiu.
\end{abstract}

Reikšminiai žodžiai: askorbo rūgštis, cukrus, Ribes nigrum, selekcija, temperatūra, titruojamasis rūgštumas, vaisių masè. 